\title{
Beğenilme Arzusu: Ölçek Geliştirme, Güvenirlik ve Geçerlik Çalışması
}

DOI: $10.21666 /$ muefd. 345573

\author{
Gülizar KAŞIKARA \\ Yüksek Lisans Öğrencisi \\ Muğla Sitkı Koçman Üniversitesi - glizarkasikara@gmail.com \\ Yrd.Doç.Dr. Uğur DOĞAN \\ Muğla Sitkı Koçman Üniversitesi - ugurdogn@gmail.com
}

\begin{abstract}
Özet
Araştırmanın amacı beğenilme arzusu ölçeğini geliştirmek, ölçeğin geçerlik ve güvenirliğini incelemektir. Araştırma pilot uygulama için 69, Açımlayıcı Faktör Analizi (AFA) için 418, Doğrulayıcı Faktör Analizi (DFA) için ise 113 öğrenci üzerinde gerçekleştirilmiştir. Ölçeğin yap geçerliğini belirlemek için AFA ve DFA yöntemleri, güvenilirliğinin belirlenmesi için de test tekrar test yöntemi, eşdeğer yarlar yöntemi, Cronbach Alpha iç tutarlık katsayısı ve düzeltilmiş madde-toplam korelasyonu kullanılmıştır. AFA çalışmasında ölçeğin toplam varyansının \%42'sini açıklayan bir yapı elde edilmiştir. AFA'ya göre, toplam 9 madde tek faktörde toplanmaktadır. Ölçekten alınan puanların yükselmesi beğenilme arzusunun yükseldiğini göstermektedir. Ölçeğe uygulanan DFA sonuçları ölçeğin tek boyutlu yapısını doğrulamıştır ( $x^{2} / s d=1.42$, RMSEA=.06, GFI=.92, $A G F I=.88, C F I=.95, I F I=.96, N F I=.87, R F I=.83, R M R=.03$, SRMR= .06 ). Beğenilme Arzusu Ölçeği'nin ölçüt geçerliğini test etmek için sosyal istenirlik ölçeğinin izlenim yönetimi alt boyutu kullanılmıştır. Yapılan analiz sonucunda beğenilme arzusuyla izlenim yönetimi arasında negatif düzeyde ilişki olduğu bulunmuştur. Güvenirlik çalışmasında iç tutarlık katsayısı, AFA'ya göre .82 iken, DFA için .81 olarak bulunmuştur. Eş değer yarılar yönteminin AFA sonuçlarına göre tek ve çift diye ayrllan iki grup arasında .72, DFA sonuçlarl için de 72 düzeyinde bir korelasyon olduğu görülmüsstür. Ölçeğin 4 hafta ara ile yapılan test-tekrar test güvenirlik çalışmasında $.73(p<.001)$ korelasyon bulunmuştur. Bir diğer güvenirlik çalışmasında \%27'lik alt ve üst gruplar arasında anlamlı bir farkın olduğu görülmüştür $(p<$.001). Son olarak madde toplam analizinde, AFA sonuçlarına göre madde toplam korelasyonları 0.46 ile 0.71 arasında değişirken, DFA sonuçlarına göre ise 0.29 ile 0.70 arasında değişmektedir. Bu bulgulara dayanarak Beğenilme Arzusu Ölçĕ̆i'nin ĕgitim ve psikoloji alanında kullanılabilecek, geçerli ve güvenilir bir ölçme aracı olduğu söylenebilir.
\end{abstract}

Anahtar Kelimeler: Beğenilme Arzusu, ölçek geliştirme, geçerlik, güvenirlik, faktör analizi

\section{Desire For Being Liked Scale: Validity And Reliability Study}

\begin{abstract}
This study aims to develop Desire for Being Liked Scale for college students, and to conduct a validity and reliability study. The pilot study was conducted on 69 students, Exploratory Factor Analysis (EFA) study was conducted on 418 students and Confirmatory Factor Analysis (CFA) was conducted on 113 students. As a result of the EFA's principal components techniqueses, a construct with nine items explaining a total of $42 \%$ of the total variance was attained. CFA revealed acceptable fit for the one-dimensional model $\left(x^{2} / s d=1.42\right.$, RMSEA=.06, GFI=.92, AGFI=.88, CFI=.95, $I F I=.96, N F I=.87, R F I=.83, R M R=.03, S R M R=.06$ ). It was also observed that the scale revealed a negative correlation validity with impression management subscale of social desirability scale. The Cronbach Alpha reliability coefficient calculated for the whole scale was found to be 0.82 for EFA, 0.81 for DFA. After an interval of 1 month, a result of the test-retest correlation coefficient was found to be 0.73 . In another reliability study, 27\% of bottom-top group comparisons revealed significant differences in all items. Finally, the item-total correlation analysis of the relationship was examined and found to vary between 0.46 and 0.70 for EFA, 0.29 and 0.70 for DFA. Based on these findings, we can say that the Desire of Being Liked Scale can be used in the field of education and psychology and that it is a reliable and valid measurement tool.
\end{abstract}

Keywords: Desire of being liked, adolescent, validity, reliability, scale development, factor analysis 
İnsan yaratılışı bakımından doğa karşısında zayıf bir varlıktır. Fizyolojik olarak varlığını devam ettirebilmek için gruplar halinde yaşamaya yani topluma ihtiyaç duymaktadır. İhtiyaçlar var olduğu sürece sosyal hayatın sürekliliği devam etmekte, sosyal hayatın sürekliliğiyle birlikte ise yeni ihtiyaçlar ortaya çıkmaktadır (Özyurt, 2005).

İnsanlar belirli amaçlar doğrultusunda çoğu zaman ihtiyaçları göz önünde bulundurarak harekete geçerler. İhtiyaçların organizmayı harekete geçirmesinin altında yatan sebep ise güdülerdir (Eroğlu, 2000). Güdüler fizyolojik ve sosyal olmak üzere iki gruba ayrılır (İşçi, 1999). Fizyolojik güdüler açlık, susuzluk, cinsellik, boşaltım, teneffüs, dinlenme, beden 1sısının dengede tutulması, uyarılma şeklinde sıralanabilir. Sosyal güdüler ise kendini gerçekleştirme, anlama itibar isteği, bağlanma ihtiyacı, iktidar isteği, kazanç isteği, bir arada olma ihtiyacı, özgürlük ve özerklik ihtiyacı v.b. şeklindedir (Taylor, 2015). Bu güdüler doyuma ulaştığında yani güdünün gereği yerine getirildiğinde organizmanın biyolojik ve ruhsal dengesi sağlanmış olur (Aytaç, 2000).

İnsan davranışlarını etkileyen en önemli etkenin ihtiyaçlar olduğunu ortaya koyan Maslow'a göre her insan farklı ihtiyaçlara sahiptir ancak bu ihtiyaçların şiddeti kişiden kişiye farklılık göstermektedir. Maslow her insanda ortak kabul ettiği beş temel ihtiyacın hiyerarşik sıralamasını şu şekilde yapmıştır: Fizyolojik ihtiyaçlar, güvenlik ihtiyaçları, ait olma ve sevgi ihtiyaçları, takdir ve saygı ihtiyaçları, kendini tamamlama ihtiyacı. Maslow'un ihtiyaçlar hiyerarşisinde üçüncü basamak "ait olma ve sevilme ihtiyacı" olarak sıralanmaktadır. Bireylerin kabul edilme, bir gruba ait olma, beğenilme arzularını bu ihtiyaç basamağı temsil etmektedir.

Sevilme ve kabul edilme ihtiyacından doğan beğenilme arzusu bireylerin kendilerini olduğundan daha olumlu görmelerine neden olabilir. Kendini olduğundan daha olumlu görme eğilimi çok yaygın bir eğilimdir ve kendini beğenme ya da beğenilme arzusundan kaynaklanmaktadır (O'Brien, 2011). Geleneksel bir ruh sağlı̆̆ anlayışı bireyin benliğinin hem olumlu hem de olumsuz yönlerinin farkındalığını ve kabulünü içeren bir görüşe sahip olduğunu iddia eder. Bu tanımlamanın aksine, kanıtlar çoğu bireyin olumlu bir benlik kavramına sahip olduğunu göstermektedir (Greenwald, 1980). Kendimizi: daha akıllı, donanımlı, güçlü ve sağlıklı; daha cömert, dürüst, olgun, yaratıcı ve olumlu; ve "diğerlerinin ortalamasından" daha az önyargılı olarak görmekte olduğumuz (Alicke ve Govorun, 2005; Dunning, Heath ve Suls, 2004) ve bu şekilde davranma eğiliminde olduğumuz belirtilmektedir. $\mathrm{Bu}$ şekilde davranma sebeplerine baktığımızda diğerlerinden olumlu geri bildirimler almak, sahip olduğumuz benlik kavramının muhafazası için önem arz etmektedir. Sosyal etkileşim normları ve stratejileri genel olarak olumlu benlik değerlendirmelerini geliştirir ve olumsuz olanlara karşı koruma sağlamaktadır. İnsanların çoğu kendilerini doğrulayan geribildirim talep etmekte ve bu geribildirimleri almayı gerekli görmektedirler (Taylor ve Brown, 1988). Örneğin, kendisini utangaç biri olarak düşünen bir kadın, kendisini bu şekilde tanımlayan geribildirim isteyebilmektedir (Swann, 1983).

Olumlu ve olumsuz kişilik sıfatlarından hangisinin kendisini tanımladığını belirtmeleri istendiğinde, normal kişiler pozitif özelliklerin, negatif özelliklere kıyasla daha fazla belirtmektedirler (Alicke, 1985; Brown, 1986). Buna ek olarak, çoğu birey için olumlu kişilik bilgileri etkili bir şekilde işlenip ve kolayca hatırlanmaktayken, negatif kişilik bilgileri kötü bir şekilde işlenmekte ve hatırlanması zor olmaktadır (Kuiper ve Derry, 1982; Kuiper ve MacDonald, 1982; Kuiper, Olinger, MacDonald ve Shaw, 1985).

Bireylerin olumlu ya da olumsuz kendilerine yönelik oluşturdukları benlik kavramları, topluma karşı geliştirdikleri etkileşim stratejilerini etkiler. İnsanların toplumsal durumlarda benimsediği etkileşim stratejileri, önceden var olan benlik kavramlarını teyit etme eğilimindedir (incelemeler için bkz. Swann, 1983, 1984). Aynı zamanda fiziksel belirtileri vasıtasıyla kendilerine nasıl davranılmasını istediklerini ima ederler (Örneğin giyim tarzı ya da takıları ile politik görüşünü sergiler). İnsanlar aktif olarak diğerlerinde yanlış izlenim oluşturmamaya çalışır (Swann ve Hill, 1982) ve benlik kavramlarını onaylayacaklarını inandıkları sosyal geri bildirimleri arama eğilimlerindedirler (Swann ve Read, 1981a, 1981b). Bireylerin çoğunun kendilerini algılamaları olumlu olmasından dolayı, bu tür stratejiler, geribildirimin öncelikle olumlu olması muhtemel olduğunda geribildirim arama eğilimine yol açar (Brown, 1987).

Günümüzde insanlar tarafından beğenilmek, alkışlanmak, onaylanmak daha da önemli bir hale gelmekte ve eksiksiz bir insan imajı sunmak baskın bir davranış olarak göze çarpmaktadır. Elbetteki kadın ya da erkek tüm bireyler beğenilmek ve kendilerini iyi hissetmek isterler. Ancak kadının 
güzelleşme isteğinin, beğenilme arzusunun, estetik kaygılarının, fark edilme isteğinin, kusursuz olma çabasının, ideale yakınlaşma hevesinin çalışmaları etkilediği görülmektedir (Uğurlu, 2015). Bu durumun kadınlarda erkeklere kıyasla daha dikkat çekici durumda olduğu söylenebilir. Bununla birlikte ergenlik döneminin de beğenilme ihtiyacının göze çarpan bir etken haline geldiği bir zaman dilimi olduğu söylenebilir. Özellikle ergenlerin akranları tarafından beğenilme ihtiyacı, kendi kişiliklerini yansıtma ihtiyaçlarından daha önemli bir etken olarak görülmektedir (Auty ve Elliott, 2001). Ergenlerin hayatlarının en önemli meseleleri akranları tarafindan kabulü, beğenip beğenilmedikleri, akranları tarafindan benimsenmeleridir (Taylor, 2015). Bu beğenilme arzusunun uyumlu mu uyumsuz mu olduğu net değildir. Taylor, Lerner, Sherman ve diğ. (2003), kendini olumlu görmenin ve akranları tarafindan beğenilmenin iyi bir ruh sağlığı ile ilişkili olduğunu bulmuştur.

Fiziksel çekicilik, kendimize benzerlik, ortak yönler ve övgüler beğenilmeye yardımcı olan etmenler olarak göze çarpmaktadır (Cialdini, 1993). Bir dizi çalışmada bireyler fiziksel olarak çekici bireyleri daha yetenekli, kibar, dürüst ve akıllı olarak değerlendirmişlerdir (Eagly, Ashmore, Makhijani ve Longo, 1991), Kendimize benzerlik (Byrne, 1971; Carli, Ganley ve Pierce-Otay, 1991) övgü veya methiye (Byrne ve Rhamey, 1965; Drachman, deCarufel ve Insko, 1978) bireyin beğenilmesine katk1 sağlar. Buna ek olarak, bir başkasının eylemlerini taklit etmek gibi sözsüz davranışlar beğenilmeyi artırır (Lakin, Jefferis, Cheng ve Chartrand, 2003).

Bir kişinin başkaları tarafından ne kadar beğenildiği, bir takım yaşam olayları ve bunların sonuçları üzerinde önemli bir etkendir. Beğenilme hissini elde etmek, insanlar için temel ve güçlü bir ihtiyaç (Baumeister ve Leary, 1995; Deci ve Ryan, 2000) olduğu kadar ve diğerleri tarafından beğenilmemek iyi oluş, ruh sağlığı, sosyal uyum ve akademik performansla daha az ilişkilidir (Coie ve Cillessen, 1993). Uygunsuz kendini olumlu görmenin kişilerarası ilişkilerdeki maliyetinin hem anti-sosyal davranışlar (Sedikides, Horton ve Gregg, 2007) hem de zayıf sosyal beceriler, düşmanlık ve sinirlilik (Colvin, Block ve Funder , 1995) olduğu görülmektedir. Kişilerarası ilişkilerde beğenilmek, erken yaşlardan başlayan bir şekilde uyum ile ilişkili olduğu görülmektedir. Bu sonuçlar yetişkinlikte de görülmekte ve bireyin sosyal destek ağlarının boyutu ve gücü sağlı̆̆ ile doğrudan ilişkilidir (Berkman, 1985; Cohen ve Wills, 1985). Başkaları tarafından daha çok sevilen kişilik tiplerini anlamayı amaçlayan çalışmalar mevcuttur, özellikle, başkalarına yönelik kişilik özellikleri (arkadaşlık başlatma ve sürdürme gibi çeşitli kişilerarası hedef çeşitleri amaçlayan) beğenilmeyle ilişkili olduğu görülmektedir (Wojciszke ve diğ., 2009).

Hangi kişilik özelliklerinin başkaları tarafından beğenildiği ve beğenilmediğinin anlaşılmasının yanı sıra, bu özelliklerin neden beğenildiğinin anlaşılması da önemlidir. Başkaları tarafindan beğenilen özelliklere ilişkin potansiyel bir açıklama, sosyal açıdan daha fazla arzulanan özelliklerin başkaları tarafından daha fazla sevilme ihtimali vardır (Walston, 1970). Başka bir deyişle, arzulanan özellikleri kendileri için onaylayan bireylerin, bu özelliklere sahip olma ve onaylama durumları nedeniyle başkaları tarafindan daha çok sevilme ihtimalleri olduğu söylenebilir.

Alanyazında beğenilme arzusuna yakın olarak sosyal istenirlik ölçeği (Paulhus, 1991; akt. Akın, 2010) ve sosyal onay ihtiyacı ölçeği (Karaşar ve Ögülmüsş, 2016) bulunmaktadır. Sosyal istenirlik ölçeği, bireylerin kendilerini olumlu sunmak için ölçme araçlarında gerçek bilgileri yerine sosyal açıdan onaylanacak cevaplar vermesine yönelik eğilimlerini içermektedir (Crowne ve Marlowe, 1960; Paulhus, 1991; akt. Akın, 2010). Bu tanımdan hareketle sosyal istenirliğin beğenilme arzusundan farklı olarak ölçme araçlarında önyargılı bir yanıtlama biçimi olduğu söylenebilir. Sosyal istenirliğin bir kişilik özelliği olduğunu savunan araştırmacılar da bulunmaktadır (Pauls ve Stemmler, 2003; akt. Akın, 2010). Kişilik özelliği olarak, zaman veya duruma bağlı olmaksızın bireyin tutarlı bir şekilde sosyal istenirlikle meşgul olmasıdır şeklinde ifade edilmektedir (Wiggins, 1973; akt. Akın, 2010). Sosyal onay ihtiyacı ölçeğinde ise bireylerin davranışlarının belirleyicisinin çevre olduğu, özellikle aile, okul ve arkadaş çevrelerinin bireyin davranışlarının ve gelişiminin şekillenmesinde önemli etkilerinin olduğu üzerinde durulmuştur. Çevrenin, bireyin elde edebileceği ödüller ve karşılaşabileceği cezalar aracılığıyla davranışların şekillenmesinde oldukça etkili olduğu belirtilmiştir (Atkinson, Atkinson, Smith, Bem ve Hoeksema, 2002; akt. Karaşar ve Öğülmüş, 2016).

Beğenilme arzusu ise bireylerin sevilme ve kabul edilme ihtiyaçları temelinde, hayatlarının birçok alanında diğer insanlardan olumlu dönüt almaya yönelik istek duymaları şeklinde belirtilebilir. Maslow'a göre bireylerin sevilme ve kabul edilme gibi sosyal ihtiyaçlarını karşılayamaması, bireylerin kendilerini yalnız ve terk edilmiş hissetmelerine neden olabilmektedir. Bu yüzden bireyler sevilme ve 
kabul edilme ihtiyaçlarını gidermeye yönelik beğenilme arzusu duymaktadırlar. Tüm bu açıklamalardan hareketle beğenilme arzusu bireylerin kendileri hakkındaki algılarını olumluya dönüştürmek, kendilerini iyi hissetmek, sevgi ve saygı ihtiyaçlarını gidermek için hayatlarının birçok alanında başkalarından olumlu dönüt almaya yönelik duydukları istek şeklinde tanımlanabilir. $\mathrm{Bu}$ çalışmanın amacı ise beğenilme arzusuyla ilgili olarak üniversite öğrencilerine yönelik, eğitim ve psikoloji alanında kullanılabilecek, geçerli ve güvenilir bir ölçme aracı geliştirmektir.

\section{Çalışma I}

\section{Çalıșma Grubu}

Araştırmanın çalışma grubu 2016-2017 Eğitim Öğretim y1lında Bahar döneminde Muğla Sitkı Koçman Üniversitesi'nde öğrenim görmekte olan 418 üniversite öğrencisinden oluşmaktadır. Çalışma grubunun 159'u erkek ve 259'u kadın öğrencilerden oluşmuştur. Çalışma grubunun \%62'si kadın, $\% 38$ 'si erkektir. Katılımcıların yaş ortalaması 21.34'tür. Araştırmaya katılan öğrenciler seçkisiz olmayan, uygun örnekleme yöntemiyle seçilmiştir.

\section{Veri Toplama Araçları}

Sosyal İstenirlik ölçeği: Bu çalışmada ölçüt geçerliği için sosyal istenirlik ölçeğinin iki alt boyutundan biri olan izlenim yönetimi boyutu kullanılmıştır. Ölçek Paulhus (1984)'un 40 maddeden ve iki alt boyuttan oluşan Dengeli Sosyal İstenirlik Ölçeği'nin Akın (2010) tarafından uyarlanmasıyla oluşturulmuştur. Toplam 29 maddeden oluşan bu ölçek öz-aldatma ve izlenim yönetimi şeklinde iki alt boyuttan oluşur. Öz aldatma boyutu bilinçdışı bir eğilim içerdiği için bu çalışmada kullanılmamıştır. İzlenim yönetimi alt boyutu 16 maddeden oluşmaktadır. SïÖ beş basamaklı Likert bir dereceleme ölçeği olup "1" Hiç uygun değil, "2" Uygun değil, "3" Biraz uygun, "4” Uygun, "5" Tamamen uygun seçeneklerinden oluşmaktadır. Ölçeğin iç tutarlılık katsayısı izlenim yönetimi alt boyutu için .96 olarak hesaplanmıştır. Test-tekrar test güvenirlik katsayıları da izlenim yönetimi alt ölçeği için .83'tür. AFA sonuçlarına göre öz-aldatma ve izlenim yönetimi faktörleri arasında -.17 ilişki bulunmuştur.

\section{İşlem}

Ölçek maddelerinin hazırlanması sürecine ilk olarak beğenilme arzusu alanında yapılan araştırmalar incelenerek başlanmıştır. Eğitim ve akademik alanlardaki indeks ve dizinlerde yayınlanan "beğenilme arzusu" başlığ 1 altındaki toplanan veriler incelenmiştir. 10 soruluk yarı yapılandırılmış bir görüşme formu hazırlanarak 10 kişiyle odak grup görüşmesi yapılmıştır. Sorular sesli olarak okunmuş, sesli olarak yanıt alınmıştır. Literatür incelemesi ve nitel görüşme göz önünde bulundurularak 50 maddelik bir madde havuzu oluşturulmuştur. Bir sonraki aşamada bu maddelerle ilgili psikolojik danışmanlık ve rehberlik alanlarında uzman olan 2 öğretim üyesinden ve bir dil uzmanından görüş alınmıştır. Uzman görüşü sonucunda 25 maddenin çıkarılmasına karar verilmiştir. Yapılan değerlendirmeler sonucunda 25 maddelik ölçek ile pilot uygulamaya geçilmiştir. 25 madde 69 kişilik bir pilot gruba uygulanmış, bu çalışma sonucunda öğrenciler tarafindan anlaşılmayan ve boş bırakılan madde bulunmamıştır. 25 madde 4 basamaklı likert bir dereceleme ölçeği ("1" hiç katılmıyorum, "2" katılmıyorum, "3" katılıyorum ve "4" tamamen katılıyorum) şeklinde yazılmış ve bu maddeler üzerinde geçerlik ve güvenirlik analizleri yapılmıştır.

\section{Geçerlik Çalışmaları}

\section{Bulgular}

Yapı Geçerliği: Beğenilme Arzusu Ölçeği'nin yapı geçerliğini incelemek amacıyla yapılan Açımlayıcı Faktör Analizi (AFA)'nde öncelikle bütün maddeler arasında korelasyon matrisi incelenerek faktör analizinin yapılabilmesine uygunluk gösterir nitelikte ilişkilerin olduğu görülmüştür. AFA yapılmadan önce verilerin faktör analizine uygunluğu Kaiser Mayer Olkin (KMO) katsayısı ve Barlett Sphericity testiyle test edilmiştir. KMO'nun 0.60'dan yüksek, Barlett testinin anlamlı çıkması verilerin faktör analizi için uygun olduğunu göstermektedir (Büyüköztürk, 2007). Bu çalışmada KMO örneklem uygunluk katsayıs1 .85, Barlett Sphericity testi $\mathrm{x}^{2}$ değeri ise 1059,360 $(p<.001)$ bulunmuştur. Alanyazında, bir maddenin faktör yük değeri için asgari büyüklüğün .32 olmas1 yönünde yaygın bir görüş vardır ,bunun yanı sıra faktör yük değerlerini değerlendirmek amacıyla yüklerin büyüklüğu için kesme noktasının ne olması gerektiğine ilişkin karar araştırmacının tercihine 
bağlıdır (Çokluk, Şekercioğlu, ve Büyüköztürk, 2010). Bu görüşle birlikte .50 faktör yük değeri kesme noktası olarak belirlenmiştir. Büyüköztürk (2010) ölçek geliştirme çalışmalarında açıklanan toplam varyansın \%41'in üzerinde olmasının ve maddelerin faktör yüklerinin .32'nin üzerinde olmasının ölçeğin geçerli sayılabilmesi için yeterli olduğunu belirtmektedir. AFA'nın temel bileşenler tekniği ile Scree Pilot sonucunda maddeler tek faktör ile sınırlandırılmıştır. Faktör yükü .50'nin altında kalan ya da binişik olan 16 madde ölçekten çıkartılmış ve toplam varyansın \%42.10'unu açıklayan, 9 maddeden oluşan tek boyutlu bir yapıya ulaşılmıştır. Ölçek maddelerine ait faktör yükleri ve açıklanan varyans Tablo 1'de verilmiştir.

Tablo 1. Beğenilme Arzusu Ölçeği'nin Maddelerine İlişkin Açımlayıcı Faktör Analizi Sonuçlarına Göre Faktör Yük Değerleri, Düzeltilmiş Madde-Toplam Korelasyonlart ve t değerleri

\begin{tabular}{|c|c|c|c|}
\hline \multirow{3}{*}{ Madde } & \multicolumn{3}{|c|}{ Açımlayıcı Faktör Analizi } \\
\hline & Faktör Yük & Madde Toplam & \\
\hline & Değerleri & Korelasyonu & değeri \\
\hline $\begin{array}{l}\text { 11. Beğenilmeyeceğimi düşünmek beni } \\
\text { endişelendirir. }\end{array}$ & .81 & .71 & $7.39 * * *$ \\
\hline 7. Beğenilmezsem kendimi değersiz hissederim. & .70 & .57 & $6,57 * * *$ \\
\hline 19.Beğenilmezsem yalnız kalacağımı düşünürüm. & .66 & .54 & $4,48 * * *$ \\
\hline $\begin{array}{l}\text { 10. Hoşlanmadığım insanların bile beni } \\
\text { beğenmesini isterim. }\end{array}$ & 64 & .53 & $6,92 * * *$ \\
\hline $\begin{array}{l}\text { 8. Davranışlarıma olumlu geribildirimler } \\
\text { almadığımda hayal kırıklığı yaşarım. }\end{array}$ & .62 & .50 & $5,35 * * *$ \\
\hline $\begin{array}{l}\text { 17. Beğeni almak beni amaçlarıma ulaştıran en } \\
\text { büyük isteklendirme kaynağıdır. }\end{array}$ & .61 & .50 & $7,08 * * *$ \\
\hline $\begin{array}{l}\text { 9. Kendim istemesem de başkaları beğendiği için } \\
\text { yaptığım şeyler vardır. }\end{array}$ & .59 & .47 & $6,62 * * *$ \\
\hline $\begin{array}{l}\text { 18. Beğenilmek için harcadığım para beni maddi } \\
\text { anlamda zorluyor. }\end{array}$ & .58 & .46 & $5,15^{* * * *}$ \\
\hline $\begin{array}{l}\text { 25. Davranışlarımı birilerinin beni izleme } \\
\text { ihtimaline göre değiştiririm. }\end{array}$ & .57 & .46 & $4,49 * * *$ \\
\hline Özdeğer & & 3,79 & \\
\hline Açıklanan Varyans & & 42.10 & \\
\hline Cronbach Alpha & & .82 & \\
\hline $\mathrm{N}: 113 * * * \mathrm{P}<.001$ & & & \\
\hline
\end{tabular}

Ölçüt Geçerliği: Bir ölçekten elde edilen puanlar, ölçeğin ölçmek istediği özellik bakımından o özelliğe sahip olanlarla olmayanları ayırt etmelidir. Bu özelliğe sahip olan ve olmayan bu iki grubu birbirinden ayırmak için ölçüt olarak daha önceden geçerli olduğu bilinen bir ölçek kullanılabilir. Her iki ölçeği aynı örneklem grubuna uyguladıktan sonra iki grubun puanları arasındaki korelasyon katsayısı hesaplanır. Korelasyon katsayısının yüksekliği ise iki ölçeğin birbirine o ölçüde benzer ölçme yaptığını göstermektedir (Tezbaşaran, 1996). Beğenilme Arzusu Ölçeği’nin ölçüt geçerliğini test etmek için Sosyal İstenirlik ölçeğinin (Akın, 2010; Paulhus, 1984) izlenim yönetimi alt boyutu kullanılmıştır. Sosyal istenirlik bireylerin beğenilmek ve onaylanmak için kültürel anlamda onaylanan cevapları vermelerini ve kendilerini bu yönde manipule etmelerini içerir. Sosyal istenirlik ölçeği beğenilme amaçlı yapılan davranışları içerdiği için bu çalışmada ölçüt geçerliği için kullanılmıştır. Öz aldatma alt boyutunun kullanılmamasının sebebi ise bilinçdışı eğilimler içermesidir (Paulhus, 1984; akt. Akın, 2010). Yapılan analiz sonucunda Sosyal İstenirlik Ölçeği'nin İzlenim yönetimi alt boyutundan alınan puanlarla Beğenilme Arzusu Ölçeği puanları arasında -.16 $(p<.001)$ ilişki bulunmuştur. Beğenilme Arzusu'nun ile Sosyal İstenirlik ölçeği İzlenim Yönetimi alt boyutu arasında negatif yönlü anlamlı bir ilişki bulunmuştur.

\section{Güvenirlik Çalışmaları}


İç Tutarlılık: Ölçeğin güvenilirliğini belirlemek için Cronbach Alpha iç tutarlılık katsayısı incelenmiştir. Cronbach Alpha güvenirlik katsayısı maddelerin tamamının bir bütün olarak ölçeğin bütünü ile ölçülmek istenen özelliği ölçüp ölçmediğine ilişkin bilgi verir. Cronbach Alpha katsayının yüksek olması maddelerin birbiriyle yüksek ilişki içinde olduğunu yani ölçeğin homojenliğini gösterir. Ölçeğin Cronbach Alpha katsayısı ne kadar yüksek olursa ölçek maddeleri o ölçüde birbiriyle tutarlı ve aynı özelliği yoklayan maddelerdir. Likert tipi bir ölçek için Cronbach Alpha güvenirlik katsayısı olabildiğince 1'e yaklaşmalıdır (Tezbaşaran, 1996). Bu ölçeğin ise AFA sonuçlarına göre Cronbach Alpha katsayısı ise .82 bulunmuştur.

Test Tekrar Test Çalışması: Ölçeğin güvenirliğini belirlemek için kullanılan yöntemlerden biri de test-tekrar test yöntemidir. Test tekrar test güvenirliği ölçme aracının uygulamadan uygulamaya tutarlı sonuçlar verebilme durumunu gösterir (Tezbaşaran, 1996). 31 kişilik bir gruba dört hafta ara ile iki uygulama yapılmıştır. Pearson Momentler Korelasyon katsayısı ile ölçeğin güvenirliği test edilmiştir. Yapılan ön test ve dört hafta sonra yapılan son test çalışmasından sonra pearson momentler korelasyon katsayısı .73 bulunmuştur. Tavşancıl'a (2010) göre güvenirlik katsayısının pozitif ve en az .70 olması gerekmektedir.

Alt-Üst Grup Güvenirliği: Güvenirliğin sağlanması için uygulanan diğer bir yol ise alt \% 27 ile üst \% 27 'lik grupların karşılaştırılması şeklindedir. Ölçme aracından alınan toplam puanlara göre oluşturulan alt \% 27 ile üst \% 27 'lik grupların ölçülen özellik bakımından farklı olması beklendiği için grupların madde ortalama puanları arasında da anlamlı bir fark olması beklenmektedir. Büyüköztürk (2007)'e göre, ölçeğin güvenirliğini gösteren bir kriter de alt ve üst grupların maddelere verdikleri yanıtlar arasında fark olmasıdır. Çalışma evreninden alınan üst \%27 (N:113) ile alt \%27(N:113) grupların madde ortalama puanları arasındaki farkların anlamlılığ için t-testi yapılmıştır. Grupların t-testi sonuçlarına göre yapılan t-testi sonucunda alt ve üst grup arasında anlamlı $(\mathrm{p}<.001)$ bir farkın olduğu bulunmuştur. Bu sonuçla ilgili olarak maddelerin iyi bir ayırt ediciliğe sahip oldukları belirtilebilir. Analize ilişkin t değerleri tablo 1'de verilmiştir.

Eş Değer Yarılar: Eşdeğer yarılar yönteminde öncelikle test bir gruba uygulanır. Testin puanlamas1 yapılmadan önce test, her form orijinal testin yarısı kadar madde sayısına sahip olacak şekilde iki forma ayrılır. Her cevaplayıcının iki yarı formdan aldığı puanlar arasındaki korelasyon Pearson Momentler Çarpımı katsayısı ile hesaplanır. Bu yarı testin güvenirlik katsayısını verir (Crocker ve Algina, 1986; akt. Soğuksu ve Alıc1, 2016). Bu ölçeğin AFA sonuçlarına göre kalan 9 madde tek ve çift numaralar olarak iki gruba ayrılmıştır. Bu iki grubun arasında .72 düzeyinde anlamlı bir ilişki olduğu görülmüştür.

Madde Toplam Korelasyon: $\mathrm{Bu}$ yöntem her madde ile ölçek puanı arasındaki korelasyon katsayısının hesaplanmasına dayanır. Herhangi bir maddede korelasyon katsayısının işareti eksi, değeri sıfır veya sıfira yakınsa bu durum, maddenin diğer maddelerin ölçmek istediği tutumu ölçmeye uzak olduğunu gösterir. Aynı şekilde ölçeği oluşturan her maddenin birbiriyle olan ilişkisinin yüksek olması da önemlidir. Maddelerin ölçek puanlarıyla ve birbirleriyle yüksek korelasyonlara sahip olmaları aynı boyutta ölçme yaptıklarını gösteren bir durumdur (Ghiselli, Campbell, Zedeck, 1981; akt. Tezbaşaran, 1996). Bu ölçeğin AFA sonuçlarına göre madde toplam korelasyonları ise 0.46 ile 0.71 arasında değişmektedir. Analize ilişkin değerler tablo 1'de verilmiştir.

Puanların Değerlendirilmesi: Ölçekten alınan puanların yükselmesi beğenilme arzusunun yükseldiğini göstermektedir.

\section{Çalışma II}

Çalışma Grubu

Ölçme aracının Doğrulayıcı Faktör Analizi (DFA) için ulaşılan çalışma grubu 2016-2017 Eğitim Öğretim yılında Bahar döneminde Muğla Sitkı Koçman Üniversitesi’nde öğrenim görmekte olan 113 üniversite öğrencisinden oluşmaktadır. Çalışma grubunun 46's1 erkek ve 67'si kadın öğrencilerden oluşmuştur. Çalışma grubunun \%59'u kadın, \%41'i erkektir. Katılımcıların yaş ortalaması 20.67'dir. Araştırmaya katılan öğrenciler seçkisiz olmayan, uygun örnekleme yöntemiyle seçilmiştir.

\section{İşlem:}

DFA kuramsal bir temelle belirli değişkenlerle oluşturulmuş faktörlerin toplanan verilerle ne derece uyum gösterdiğini incelemeye yönelik bir analizdir. Yani daha önce tanımlanan ve sınırlanan bir yapının, doğrulup doğrulanmadığının test edildiği bir analizdir (Sümer, 2000). DFA, faktör modelinin 
veriye uygunluğunu değerlendiren en etkili analizdir. Ölçme araçlarını geliştirme, düzenleme ve yeniden gözden geçirme durumlarında kullanışlı bir analiz olarak karşımıza çıkmaktadır (Floyd ve Widaman, 1995; akt. Çokluk, Şekercioğlu ve Büyüköztürk, 2010).

\section{Geçerlik Çalışmaları}

Yapı Geçerliği: Ölçeğin yapı geçerliğini test etmek için DFA'dan yararlanılmıştır. Beğenilme Arzusu Ölçeğin'in DFA analizi sonucunda elde edilen değerleri tablo 2'de verilmiştir

Tablo 2. Bĕgenilme Arzusu Ölçeğin'in Maddelerine İlişkin Doğrulayıcı Faktör Analizi sonuçlarına göre Faktör Yük Değerleri, Düzeltilmiş Madde-Toplam Korelasyonları ve T değerleri

\begin{tabular}{|c|c|c|c|}
\hline \multirow{4}{*}{ Madde } & \multicolumn{3}{|c|}{ Doğrulayıcı Faktör Analizi } \\
\hline & Faktör Yük & Madde & T değeri \\
\hline & Değerleri & Toplam & \\
\hline & & Korelasyon & \\
\hline $\begin{array}{l}\text { 11. Beğenilmeyeceğimi düşünmek beni } \\
\text { endişelendirir. }\end{array}$ & .80 & .70 & $9,45 * * *$ \\
\hline 7. Beğenilmezsem kendimi değersiz hissederim. & .62 & .53 & $-8,05 * * *$ \\
\hline $\begin{array}{l}\text { 19.Beğenilmezsem yalnız kalacağımı } \\
\text { düșünürüm. }\end{array}$ & .73 & .63 & $-9,28 * * *$ \\
\hline $\begin{array}{l}\text { 10. Hoşlanmadığım insanların bile beni } \\
\text { beğenmesini isterim. }\end{array}$ & .48 & .44 & $-6,67 * * *$ \\
\hline $\begin{array}{l}\text { 8. Davranışlarıma olumlu geribildirimler } \\
\text { almadığımda hayal kırıklığı yașarım. }\end{array}$ & .50 & .41 & $-5,53 * * *$ \\
\hline $\begin{array}{l}\text { 17. Beğeni almak beni amaçlarıma ulaştıran en } \\
\text { büyük isteklendirme kaynağıdır. }\end{array}$ & .50 & .47 & $-5,79 * * *$ \\
\hline $\begin{array}{l}\text { 9. Kendim istemesem de başkaları beğendiği için } \\
\text { yaptığım şeyler vardır. }\end{array}$ & .29 & .29 & $-4,97 * * *$ \\
\hline $\begin{array}{l}\text { 18. Beğenilmek için harcadığım para beni maddi } \\
\text { anlamda zorluyor. }\end{array}$ & .66 & .59 & $-9,06 * * *$ \\
\hline $\begin{array}{l}\text { 25. Davranışlarımı birilerinin beni izleme } \\
\text { ihtimaline göre değiştiririm. }\end{array}$ & .61 & .57 & $-10,09 * * *$ \\
\hline $\begin{array}{l}\text { Cronbach Alpha } \\
\mathrm{N}: 113 * * * \mathrm{P}<.001\end{array}$ & & .81 & \\
\hline
\end{tabular}

DFA ile sinanan modelin uyum indeksleri incelendiğinde ise iyi uyum indekslerine sahip olduğu görülmüştür $\left(\mathrm{x}^{2}=38,529, \mathrm{sd}=27, \mathrm{p}=.000, \mathrm{x}^{2} / \mathrm{sd}=1.42\right.$, RMSEA $=0.06, \mathrm{GFI}=0.92, \mathrm{AGFI}=0.88, \mathrm{CFI}=0.95$, $\mathrm{IFI}=0.96, \mathrm{NFI}=0.87, \mathrm{RFI}=0.83, \mathrm{RMR}=0.03, \mathrm{SRMR}=0.06$ ).

\section{Güvenirlik Çalışmaları}

İç Tutarlılık: Ölçeğin güvenilirliğini belirlemek için Cronbach Alpha iç tutarlılık katsayısı incelenmiş ve DFA sonuçlarına göre .81 olduğu görülmüştür. Cronbach Alpha katsayının yüksek olmas1 maddelerin birbiriyle yüksek ilişki içinde olduğunu yani ölçeğin homojenliğini gösterir. Ölçeğin Cronbach Alpha katsayısı ne kadar yüksek olursa ölçek maddeleri o ölçüde birbiriyle tutarlı ve aynı özelliği yoklayan maddelerdir (Tezbaşaran, 1996).

Alt-Üst Grup Güvenirliği: Büyüköztürk (2007) ölçeğin güvenirliğini gösteren diğer bir kriter olarak alt ve üst grupların maddelere verdikleri yanıtlar arasında fark olması gerektiğini ifade etmiştir. Çalışma evreninden alınan üst \%27 (N:30) ile alt \%27(N:30) grupların madde ortalama puanları arasındaki farkların anlamlılı̆̆ için t-testi yapılmıştır. Grupların t-testi sonuçlarına göre yapılan t-testi sonucunda alt ve üst grup arasında anlamlı $(\mathrm{p}<.001)$ bir farkın olduğu bulunmuştur. Analize ilişkin $\mathrm{t}$ değerleri tablo 2'de verilmiştir. Bu sonuçla ilgili olarak maddelerin iyi bir ayırt ediciliğe sahip oldukları belirtilebilir.

Eş Değer Yarılar: Ölçeğin güvenirliğini test ettiğimiz diğer bir yöntem olan eşdeğer test yarılar yöntemiyle, DFA sonuçlarına göre kalan 9 madde tek ve çift numaralar olarak iki forma ayrılmıştır. 
Her cevaplayıcının iki yarı formdan aldığı puanlar arasındaki korelasyon Pearson Momentler Çarpımı katsayısı ile hesaplanır. Bu iki formun arasında .72 düzeyinde anlamlı bir ilişki olduğu görülmüştür.

Madde Toplam Korelasyon: Madde toplam korelasyonu, her madde ile ölçek puanı arasındaki korelasyon katsayısının ve ölçeği oluşturan her maddenin birbiriyle olan ilişkisinin yüksek korelasyonlara sahip olmalarını gerektiren bir durumdur(Ghiselli, Campbell, Zedeck, 1981; akt. Tezbaşaran, 1996). Bu ölçek için DFA sonuçlarına göre madde toplam korelasyonları 0.29 ile 0.70 arasında değişmektedir. Analize iliş̧in değerler tablo 1'de verilmiştir.

\section{Tartışma}

Beğenilme Arzusu Ölçeği, bireylerin beğenilmek için duydukları isteği belirlemek amacıyla geçerlik ve güvenirlik çalışması yapılmış bir ölçektir. Ölçek "1-Hiç Katılmıyorum" ve "4-Tamamen Katılıyorum" olmak üzere 4'lü likert tipindedir. Toplam 9 maddeden oluşan ölçek tek boyutludur. Ölçek ters madde içermemektedir. Ölçeğin geliştirme çalışması iki aşamadan oluşmaktadır. Birinci aşamada ölçeğin yapı geçerliğini ortaya koymak için 418 kişiyle AFA yapılmıştır. Toplam varyansın \%42.10'unu açıklayan 9 maddeden oluşan bir yapı elde edilmiştir. Bu yapının iç tutarlık katsayısı, AFA'ya göre .82 olarak bulunmuştur. Ölçeğin güvenirliğini belirlemek için dört hafta ara ile yapılan test-tekrar test analizi sonucunda .73 korelasyon bulunmuştur. Güvenirliği belirlendiği diğer bir çalışma olan alt-üst grup çalışmasında t-testi sonuçlarına göre iki grup arasında anlamlı bir fark olduğu belirlenmiştir. Eş değer test yarılar yöntemine göre ölçek maddeleri iki gruba ayrılmış, grupların arasında .72 düzeyinde anlamlı bir ilişki olduğu görülmüştür.

Ölçme aracının geliştirilmesi için ikinci aşamada, AFA sonucunda elde edilen yapıya 113 öğrencide elde edilen veriler ile DFA yapılmıştır. DFA sonucuna göre iyi uyum indekslerine sahip olduğu görülmüştür $\left(\mathrm{x}^{2}=38,529, \mathrm{sd}=27, \mathrm{p}=.000, \mathrm{x}^{2} / \mathrm{sd}=1.42\right.$, RMSEA=0.06, GFI=0.92, AGFI=0.88, CFI=0.95, $\mathrm{IFI}=0.96, \mathrm{NFI}=0.87, \mathrm{RFI}=0.83, \mathrm{RMR}=0.03, \mathrm{SRMR}=0.06$ ). DFA çalışma grubunun güvenirlik analizi için iç tutarlık katsayısının .81 olduğu, eş değer test yarılar yöntemine göre iki grup arasındaki ilişkinin .72, \%27 alt-üst grup analizinde bütün maddeler arasında anlamlı bir fark olduğu, madde toplam korelasyonunda ise değerlerin 0.29 ile 0.70 arasında değiştiği görülmüştür.

Günümüzde insanlar tarafından beğenilme arzusu daha da önemli bir hale gelmekte ve beğenilme için gösterilen çaba baskın bir davranış olarak göze çarpmaktadır. Alanyazın incelendiğinde beğenilme arzusuyla ilişkili olarak, bireylerin kendilerini olumlu sunmak için ölçme araçlarında gerçek bilgileri yerine sosyal açıdan onaylanacak cevaplar vermelerine yönelik eğilimlerini içeren sosyal istenirlik ölçeğinin (Akın, 2010; Paulhus, 1984) olduğu görülmektedir. Bunun dışında bireylerin davranışlarının şekillenmesinde çevrenin önemli etkilerinin olduğunu belirten sosyal onay ihtiyacı ölçeği (Karaşar ve Öğülmüş, 2016) bulunmaktadır. Sosyal istenirlik ölçeğinin bireylerin kabul görmek için ölçme araçlarında kendilerini olduklarından daha olumlu gösterme eğilimlerini içerdiği, sosyal onay ihtiyacı ölçeğinin ise bireylerin davranışlarında çevrenin etkilerini ve başkalarından onay bekleme eğilimlerini içerdiği söylenebilir. Beğenilme arzusu ölçeği ise bireylerin kendileri hakkındaki algılarını olumluya dönüştürmek, kendilerini iyi hissetmek, sevgi ve saygı ihtiyaçlarını gidermek amacıyla hayatlarının birçok alanında başkalarından olumlu dönüt almaya yönelik istek duymalarını içermektedir. Bu alanda ölçeğin alanyazına katkı sağlayacağı düşünülmüş̧ür. Araştırma sonuçları da Beğenilme Arzusu Ölçeğinin üniversite öğrencileri için geçerli ve güvenilir bir ölçek olduğunu göstermektedir.

Tüm bu bulgularla birlikte çalışmanın bazı sınırlılıkları vardır. Örneklem yalnızca bir devlet üniversitesinin farklı bölümlerinde eğitim gören öğrencilerden oluştuğu için, ölçeğin test edilen yapısı bu örneklem için geçerlidir. Dolayısıyla farklı örneklemlerde kullanılarak temsil edilebilirliğin arttırılması önerilebilir. Bundan sonraki çalışmalarda ölçeğin diğer yaş gruplarına da uygulanabilir hale getirilmesi için araştırmalar yapılabilir. Araştırmanın diğer bir sınırlılığı da araştırma grubunun çoğunluğunun kız öğrencilerden oluşmasıdır. Beğenilme arzusunun belirgin olarak ortaya çıktığı alanlardan biri de sosyal medyadır. Gelecek araştırmalarda beğenilme arzusunun sosyal medya kullanıcıları üzerindeki etkileri çeşitli değişkenlerle birlikte araştırılabilir. 


\section{Kaynakça}

Akın, A. (2010). İki boyutlu sosyal istenirlik ölçeğinin geliştirilmesi ve psikometrik özelliklerinin araştırılması. Gazi Eğitim Fakültesi Dergisi, 30(3), 771-784.

Alicke, M. D. (1985). Global self-evaluation as determined by the desirability and controllability of trait adjectives. Journal of Personality and Social Psychology, 49,1621-1630.

Alicke, M. D. \& Govorun, O. (2005). The better-than-average effect. In M. D. Alicke, D. A. Dunning \& J. I Krueger (Eds.), The Self in Social Judgment (pp. 85-106). New York: Taylor and Francis.

Auty, S. \& Elliott, R. (2001). Being like or being liked: identity vs. approval in a social context. ACR North American Advances, 28, 235-241.

Aytaç, S. (2000). İnsanı Anlama Çabası. Bursa: Ezgi Kitabevi.

Baumeister, R. F. \& Leary, M. R. (1995). The need to belong: Desire for interpersonal attachments as a fundamental human motivation. Psychological Bulletin, 117, 497-529.

Berkman, L. F. (1985). The relationship of social networks and social support to morbidity and mortality. In S. Cohen ve S. L. Syme (Eds.), Social Support and Health 241-259. Academic Press: Orlando.

Brown, J. D. (1986). Evaluations of self and others: Self-enhancement biases in social judgments. Social Cognition, 4, 353-376.

Büyüköztürk, Ş. (2007). Sosyal bilimler için veri analizi el kitabı(7 ed.). Ankara: Pegem A Yayıncılık. Büyüköztürk, Ş. (2010). Sosyal bilimler için çok değiş̧kenli istatistik. Ankara. Pegem A Yayıncılık.

Byrne, D. (1971). The attraction paradigm. New York: Academic Press.

Byrne, D. \& Rhamey, R. (1965). Magnitude of positive and negative reinforcements as a determinant of attraction. Journal of Personality and Social Psychology, 2(6), 884-889.

Carli, L. L., Ganley, R. \& Pierce-Otay, A. (1991). Similarity and satisfaction in roommate relationships. Personality and Social Psychology Bulletin, 17(4), 419-426.

Cialdini, R. B. (2001). Science and practice. New York: Pocket Books.

Cohen, S. \& Wills, T. A. (1985). Stress, social support, and the buffering hypothesis. Psychological Bulletin, 98, 310-357.

Coie, J. D. \& Cillessen, A. H. N. (1993). Peer rejection: Origins and effects on children's development. Current Directions in Psychological Science, 2, 89-9

Colvin, C. R., Block, J. \& Funder, D. C. (1995). Overly positive self-evaluations and personality: negative implications for mental health. Journal of personality and social psychology, 68(6), 1152.

Çokluk, Ö., Şekercioğlu, G., \& Büyüköztürk, Ş. (2010). Sosyal bilimler için çok değişkenli istatistik. SPSS ve LISREL uygulamaları. Ankara: Pegem Akademi.

Deci, E. \& Ryan, R. (2000). The 'what' and 'why' of goal pursuits: Human needs and the self-) determination of behavior. Psychological Inquiry, 11, 227-268.

Drachman, D. \& Insko, C. A. (1978). The extra credit effect in interpersonal attraction. Journal of Experimental Social Psychology, 14(5), 458-465.

Dunning, D., Heath, C. \& Suls, J. M. (2004). Flawed self-assessment: Implications for health, education, and the workplace. Psychological Science in the Public Interest, 5, 69-106.

Eagly, A. H., Ashmore, R. D., Makhijani, M. G. \& Longo, L. C. (1991). What is beautiful is good, but...: A meta-analytic review of research on the physical attractiveness stereotype. Psychological bulletin, 110(1), 109-128.

Eroğlu, F. (2000). Davranış bilimleri (5.Bask1). Kırklareli: Beta.

Greenwald, A. G. (1980). The totalitarian ego: Fabrication and revision of personal history. American Psychologist, 35,603-618.

İşçi, M. (1999). Davranış bilimleri (Genişletilmiş 2.Bask1). İstanbul: Der.

Karaşar, B. \& Öğülmüş, S. (2016). Üniversite Öğrencilerinde Sosyal Onay İhtiyacının Çeşitli Değişkenler Açısından İncelenmesi. Uludağ Üniversitesi Ĕ̆itim Fakültesi Dergisi, 29(2), 469495

Kuiper, N. A. \& Derry, P. A. (1982). Depressed and nondepressed content self-reference in mild depressives. Journal of personality, 50(1), 67-80. 
Kuiper, N. A., Olinger, L. J., MacDonald, M. R. \& Shaw, B. F. (1985). Self-schema processing of depressed and nondepressed content: The effects of vulnerability on depression. Social Cognition, 3,17-93.

Kuiper, N. A. \& MacDonald, M. R. (1982). Self and other perception in milddepressives. Social Cognition, 1, 233-239.

Lakin, J. L., Jefferis, V. E., Cheng, C. M. \& Chartrand, T. L. (2003). The chameleon effect as social glue: Evidence for the evolutionary significance of nonconscious mimicry. Journal of nonverbal behavior, 27(3), 145-162.

O'Brien, K. A. (2011). Attenuating desirable responding: a comparison of self-compassion and selfaffirmation strategies. University of Manitoba (Canada).

Özyurt, C. (2005). Modern toplumun çözümlenmesi. İstanbul: Açılım kitap.

Sedikides, C., Horton, R. S. \& Gregg, A. P. (2007). The why's the limit: curtailing self-enhancement with explanatory introspection. Journal of Personality, 75(4), 783- 824.

Soğuksu, Y. B. \& Alıcı, D. (2016). Eşdeğer yarılar güvenirliğinin farklı homojenlik düzeylerindeki örneklem büyüklüklerinde, test uzunluğuna, yarıya bölme yöntemlerine ve güvenirlik kestirme tekniklerine göre incelenmesi. Mersin Üniversitesi Ĕ̈itim Fakültesi Dergisi, 12(1).

Sümer, N. (2000). Yapısal eşitlik modelleri: Temel kavramlar ve örnek uygulamalar. Türk Psikoloji Yazılarl, 3(6), 49-74.

Swann, W. B., Jr. (1983). Self-verification: Bringing social reality into harmony with the self. In J. Suls \& A. G. Greenwald (Eds.), Social psychology perspectives 2, 33-66. Hillsdale, NJ: Erlbaum

Swann, W. B., Jr. (1984). Quest for accuracy in person perception: A matter of pragmatics. Psychological Review, 91, 457-477.

Swann, W. B., Jr. \& Hill, C. A. (1982). When our identities are mistaken: Reaffirming selfconceptions through social interaction. Journal of Personality and Social Psychology, 43, 5966.

Swann, W. B., Jr. \& Read, S. J. (1981a). Acquiring self-knowledge: The search for feedback that fits. Journal of Personality and Social Psychology, 41, 1119-1128.

Swann, W. B., Jr. \& Read, S. J. (1981b). Self-verification processes: How we sustain our selfconceptions. Journal of Experimental Social Psychology, 17, 351-370.

Tavşancıl, E. (2010). Tutumların ölçülmesiyle SPSS ile veri analizi (4. Baskı). Ankara: Nobel Yayın Dağıtım.

Taylor, I. H. (2015). Facebook and the being Liked Motive. International Journal of Social Sciences and Education Research, 1(4), 1473-1486.

Taylor, S. E. \& Brown, J. D. (1988). Illusion and well-being: a social psychological perspective on mental health. Psychological bulletin, 103(2), 193.

Taylor, S. E., Lerner, J. S., Sherman, D. K., Sage, R. M. \& McDowell, N. K. (2003). Are selfenhancing cognitions associated with healthy or unhealthy biological profiles?. Journal of personality and social psychology, 85(4), 605.

Tezbaşaran, A. (1996). Likert tipi ölçek geliştirme kılavuzu. Ankara: Türk Psikologlar Derneği Yayınları.

Uğurlu, Ö. (2015). Kadının Benlik Sunumunun Güncel Bir Aracı Olarak Sosyal Ağlar Bir Tasarım Unsuru:"Kusursuzlaştırma”. Uşak Üniversitesi Sosyal Bilimler Dergisi, 8(1), 231-247.

Walston, E. (1970). The effect of self-esteem on liking for dates of various social desirabilities. Journal of Experimental Social Psychology, 6, 248-253.

Wojciszke, B., Abele, A. E. \& Baryla, Wieslaw. (2009). Two dimensions of interpersonal attitudes:Liking depends on communion, respect depends on agency. European Journal of Social Psychology, 39, 973-990. 